\title{
Toxoplasma gondii in Cattle, Camels and Sheep in Isfahan and Chaharmahal va Bakhtiary Provinces, Iran
}

\author{
Faham Khamesipour $^{1, *}$; Abbas Doosti ${ }^{2}$; Hamid Iranpour Mobarakeh ${ }^{3}$; Erick V.G. Komba ${ }^{4}$ \\ ${ }_{1}^{1}$ Young Researcher and Elite Club, Shahrekord Branch, Islamic Azad University, Shahrekord, IR Iran \\ ${ }^{2}$ Biotechnology Research Center, Shahrekord Branch, Islamic Azad University, Shahrekord, IR Iran \\ 3 Faculty of Veterinary Medicine, Shahrekord Branch, Islamic Azad University, Shahrekord, IR Iran \\ ${ }^{4}$ Fepartment of Veterinary Medicine and Public Health, Sokoine University of Agriculture, Morogoro, Tanzania \\ ${ }^{*}$ Corresponding author: Faham Khamesipour, Young Researchers and Elite Club, Shahrekord Branch, Islamic Azad University, Shahrekord, IR Iran. P.O. Box: 166, Tel: +98-9134132858, \\ Fax: +98-3813361060, E-mail: Dr_Faham@yahoo.com, F.Khamesipour@iaushk.ac.ir
}

Received: January 8, 2014; Revised: March 18, 2014; Accepted: March 28, 2014

\begin{abstract}
Background:Toxoplasma gondii is a zoonotic parasite, which is assumed to have cosmopolitan distribution.
Objectives: Adopting a cross-sectional study design the current research aimed to determine the occurrence of the parasite in cattle, camels and sheep in Isfahan and Chaharmahal va Bakhtiary provinces of Iran.

Materials and Methods: Animals in the field and those brought for slaughter at abattoirs were included. Blood samples were randomly collected from animals and investigated by polymerase chain reaction (PCR).

Results: $T$. gondii infections were detected in $0.00 \%, 6.60 \%$ and $17.9 \%$ of the sample cattle $(n=155)$, camels $(n=122)$ and sheep $(n=95)$ respectively. Sheep were more frequently affected in Chaharmahal va Bakhtiary (33.33\%) compared to Isfahan (8.47\%) $(\mathrm{P}=0.005,95 \%$; $\mathrm{CI}$ $=6.88$-43.35). No statistically significant difference was observed in infection prevalence between camels and sheep; and between the different sex categories in both camels and sheep.

Conclusions: Evidence of T.gondii occurrence in sheep and camels was provided in the provinces under study. There is a need to investigate the potential risk factors of zoonotic infections. Furthermore, animal health and production losses caused by the parasite; and associated zoonotic implications in the area under study need to be explored.
\end{abstract}

Keywords:Blood; Polymerase Chain Reaction; Ruminants; Toxoplasma; Iran

\section{Background}

Toxoplasma gondii is a multi-host obligate intracellular protozoan parasite, causing zoonotic infections throughout the world. Definitive hosts for this coccidian parasite are felids (both domestic and wild); and the intermediate hosts are mammals and birds $(1,2)$. The felids disseminate oocysts into the environment, where they can infect all types of warm-blooded animals (wildlife, companion animals, domestic livestock), including humans. The intermediate hosts can be infected by ingesting food or water contaminated with oocysts, eating undercooked meat with tissue cysts or by transplacental infection with tachyzoites $(2,3)$.

Humans acquire toxoplasmosis mainly through ingestion of tissue cysts present in undercooked meat or by accidentally ingesting oocyst (4). Infections involving immunocompetent humans usually result in asymptomatic cases, although cervical lymphadenopathy or ocular diseases occur in some of them (up to 10\%). Occurrence of the parasite in immunocom-promised hosts and infants can however be an important cause of morbidity and mortality, causing serious disease symptoms (5, 6). In immunodeficient individuals such as HIV patients, the parasites can cause severe toxoplasmic encephalitis (7, 8). Infections in infants can cause mental retardation, loss of vision and jaundice.

In Iran about $50 \%$ of the human population has been exposed to T. gondii, which makes toxoplasmosis one of the major public health problems (9). Contact and interaction between domesticated animals and humans are known to be responsible for an increased risk of transmission of the parasite (10).

\section{Objectives}

There is a need for regular updates on the prevalence rates of this zoonotic pathogen in different animal species in order to provide useful epidemiological data to plan control strategies and eventually stem the consequences associated with the pathogens. The current study aimed to determine the presence of $T$. gondii in the blood samples of cattle, camels and sheep in Isfahan 
and Chaharmahal va Bakhtiary provinces by Polymerase Chain Reaction (PCR) method. The obtained information through this sensitive technique would add value to the available data most of which rely on serology.

\section{Materials and Methods}

\subsection{Study Area}

The present study was conducted in Isfahan and Chaharmahal va Bakhtiary provinces, Central and SouthWest of Iran respectively. Livestock production in Isfahan province is mostly traditional whereas in Chaharmahal va Bakhtiary province commercial livestock production is common. Samples were collected from randomly selected cattle, camels and sheep from slaughterhouses and peripheral farms.

\subsection{Study Design, Sample Size Determination and Animal Sampling}

It was a cross-sectional study conducted from January to March 2013. Blood samples were collected from the jugular veins of 155, 122 and 95 randomly selected cattle, camels and sheep, respectively. Respective numbers of samples from the abattoirs and farms were 100 and 55 for cattle, 90 and 32 for camels; and 65 and 30 for sheep, respectively. Five milliliters of blood was collected from each animal, stored in heparinized vacutainer tubes and conveyed on ice to the laboratory for analysis.

\subsection{DNA Extraction}

Genomic DNA was extracted from blood specimens using CinnaGen DNA extraction kit (Cinnagen, Tehran, Iran) according to the manufacturer's instructions. The extracted DNA was quantified by spectrophotometric measurement at a wavelength of $260 \mathrm{~nm}$ according to the method described by Sambrook and Russell (11). Extracted DNA samples were stored frozen at $-20^{\circ} \mathrm{C}$ until used for molecular analysis using PCR at the Biotechnology Research Center of the Islamic Azad University of Shahrekord.

\subsection{Gene Amplification}

The PCR was performed on $50 \mu \mathrm{L}$ total reaction volume including $5 \mu \mathrm{L}$ of 10x PCR buffer [70 mM Tris- $\mathrm{HCl}$ ( $\mathrm{pH} 8.8$ ), $200 \mathrm{mM}\left(\mathrm{NH}_{4}\right) \mathrm{So}_{4}, 0.1 \%$ Tween 20], $2 \mathrm{mM} \mathrm{MgCl}_{2}, 250 \mu \mathrm{M}$ of each of the four deoxynucleotide triphosphate, $1.25 \mathrm{U}$ Taq DNA polymerase (Fermentas, city, Country), 50 pmol of each Species-specific oligonucleotide primers sized 171 base pares (Toxo-F: 5'-CATTGGAGAGATTTGCATTC-3') and (Toxo-R: 5'-ATCAGTATCCCAACAGAGACAC-3') (Cinnagen, Tehran, Iran) designed from $18 \mathrm{~S}$ ribosomal RNA gene of Toxoplasma (Accession number: JQ235842) and $5 \mu \mathrm{L}$ of the extracted template DNA. Amplification of parasite DNA was done in (Eppendorf, Hamburg, Germany). DNA amplification was performed in a thermocycler apparatus for 33 cycles as follows: primary denaturation of the samples was performed at $94^{\circ} \mathrm{C}$ for 7 minutes, denaturation at $94^{\circ} \mathrm{C}$ for 1 minute, annealing at $56^{\circ} \mathrm{C}$ for 1 minute, extension at $72^{\circ} \mathrm{C}$ for 1 minute and final extension at $72^{\circ} \mathrm{C}$ for 5 minutes.

\subsection{Analysis of PCR Products}

Distilled water served as the negative control. Polymerase chain reaction products were run using 1.5\% agarose gel in $1 \mathrm{X}$ TBE buffer at $80 \mathrm{~V}$ for 30 minutes, stained with ethidium bromide and the images were visualized in UVIdoc gel documentation systems (Uvitec, UK). The PCR products (171bp) were identified by $100 \mathrm{bp}$ DNA size marker (Fermentas, Germany) (Figure 1).

\subsection{Statistical Analysis}

The obtained data were analyzed using SPSS (Statistical Package for the Social Sciences) software (Version 17. SPSS Inc, USA). Descriptive statistics were used to determine proportions of positive animals for T. gondii. The differences in proportions between animal species, different sexes and locations were determined by the Chi square test at $\mathrm{P} \leq 0.05$.

\section{Results}

In the present study a total of 155 cattle, 122 camels and 95 sheep were selected as samples from the two provinces.

\begin{tabular}{lcc}
\hline \multicolumn{1}{l}{ Table 1. PCR Test Results For Toxoplasmosis in Camels and Sheep in Isfahan and Chaharmahal Va Bakhtiary Provinces, Iran } \\
\hline Attribute & \multicolumn{2}{c}{ Prevalence of T. gondii } \\
\cline { 2 - 3 } & \multicolumn{1}{c}{ Camel } & Sheep \\
\hline Province & - & $33.33 \%(12 / 36)$ \\
\hline Chaharmahal va Bakhtiary & $6.60 \%(8 / 122)$ & $8.47 \%(5 / 59)$ \\
Isfahan & & $19.72 \%(14 / 71)$ \\
Sex & $5.17 \%(3 / 58)$ & $12.5 \%(3 / 24)$ \\
\hline Female & $6.76 \%(5 / 74)$ & \\
Male & & \\
\hline
\end{tabular}


Figure 1. Ethidium Bromide-Stained Agarose Gel Electrophoresis of PCR Products (171 bp) to detect Toxoplasma gondii in Cattle, Camel and Sheep Blood

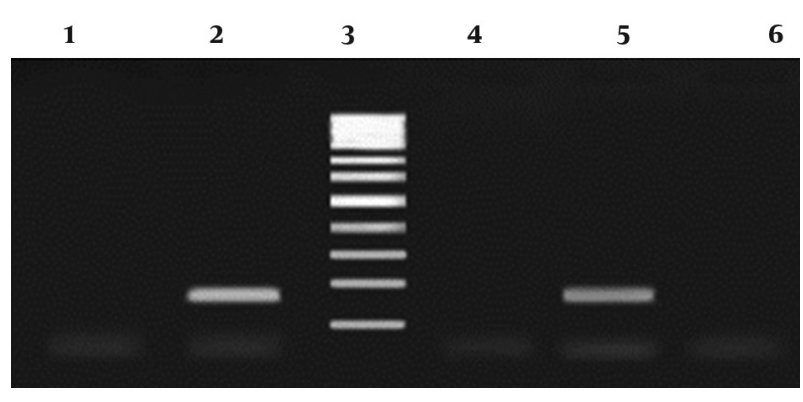

Lane 1: Negative control; lanes 2 and 5: positive samples (171 bp); lane 3:100 bp DNA ladder; and lanes 4 and 6: negative samples.

No evidence of contamination with T. gondii was detected in the sample cattle using PCR method. The overall prevalence of $T$. gondii in camels was $6.6 \%$ while the overall prevalence of the parasite in sheep was $17.9 \%$. The distribution of $T$. gondii in camels and sheep in the two provinces is presented in Table 1 . Table 1 also displays the infections in the different sex categories. No statistically significant differences were observed between camels and sheep, male and female camels, and male and female sheep. In sheep, however, the prevalence of T. gondii was significantly higher in Chaharmahal VA Bakhtiary (33.33\%) compared to Isfahan $(8.47 \%)(\mathrm{P}=0.005,95 \% \mathrm{CI}$ 6.88-43.35).

\section{Discussion}

The current study recorded a $0.00 \%$ prevalence of $T$. gondii infection in cattle $(\mathrm{n}=155)$. This finding is consistent with previous reports in the country in which no evidence of $T$. gondii infection was noted in cattle (12, 13). Several other studies have recorded lower infection levels of T. gondii in these animal species (14-22). The obtained results, showing no or lower $T$. gondii infections in cattle, are in support of the hypothesis that cattle are not a favoured host for T. gondii, and that human infection is most likely associated with consumption of pig, lamb and goat meat (13, 20, 23-25). However, other studies (26-28) have obtained high levels of $T$. gondii infection among cattle thereby contradicting the hypothesis. Variations in the levels of infection with T. gondii among cattle in the different studies could probably reflect differences in exposure rates to the parasite, which is attributable to the contamination rate of the environment.

According to Dubey and Thulliez (29), cattle have a high natural resistance to T. gondii and infection in them does not usually cause clinical symptoms. T. gondii infections in sheep and goats are known to induce abortions, pre-term deliveries, weak newborns and neonatal mortality (30-33). This frustrates scientific endeavours of geneticists, nutritionists and livestock breeders working for the propagation of small stock. It is a drain of breeding animals and thus heightens the gap of animal proteins between an increasing human population. In the current study the prevalence of $T$. gondii infection in the sheep samples was at $17.90 \%$. T. gondii infections in sheep have been also observed in a number of investigations worldwide (12, 14-16, 18, 20-22, 26-28, 34-37). Considering reproductive losses caused by the parasite, these results imply substantial economic losses to the sheep raising industry worldwide (38).

Among the sample camels $(n=122) 6.60 \%$ were infected with T. gondii. A more or less similar prevalence of the parasite in camels (4.2\%) was obtained in a previous investigation conducted in the country (39). High levels of infection with $T$. gondii among camels have been found in Saudi Arabia (40), Sudan (41) and Egypt (42). It is noteworthy that in the current study no association was found between the prevalence of T. gondii and sex, both in camels and sheep. A similar observation was made in a study conducted in Nigeria (43). However, studies in Ghana (44), Pakistan (45), Brazil (46) and China (47) revealed higher prevalence of $T$. gondii in female than in male sheep.

Some authors have indicated that female animals are more susceptible to infections with protozoan parasites than males (48). According to Kittas et al. (49) innate immune responses are enhanced in males. A significantly higher prevalence of $T$. gondii was recorded in the sheep raised in Chaharmahal va Bakhtiary than the ones raised in Isfahan. This is in accordance with previous findings which also identified geographical differences in T. gondii infections among animals (18, 50-52). This observation could be an attribute of differences in levels of environmental contamination. Investigations elsewhere have attributed human population density to geographical differences in the prevalence of protozoan parasites among animals (53).

Overall, the results of the present study confirm that T. gondii is prevalent; and that the infection is widely distributed in camels and sheep in the two provinces. There is a need to investigate the potential risk factors for infection of humans with the zoonotic parasites. Zoonotic implication of the parasite associated animal health and production losses in the area under study still need to be explored.

\section{Acknowledgements}

The authors would like to express their deep gratitude to the staff of the Biotechnology Research Center of the Islamic Azad University of Shahrekord Branch in Iran, and also livestock owners and abattoir personnel in the study areas for their cooperation.

\section{Authors' Contributions}

All authors had an equal role in the design, work, statistical analysis and manuscript writing. 


\section{Financial Disclosure}

The authors declare that they have no conflict of interest regarding the study design, study area and study findings.

\section{Funding/Support}

The present study has received no financial supports.

\section{References}

1. Nematollahi A, Moghddam G. Survey on Seroprevalence of AntiToxoplasma Gondii Antibodies in Cattle in Tabriz (Iran) by IFAT. Am J Anim Vet Sci. 2008;3(1):40-2.

2. Dubey JP, Jones JL. Toxoplasma gondii infection in humans and animals in the United States. Int J Parasitol. 2008;38(11):1257-78.

3. Dubey JP. Toxoplasma gondii infections in chickens (Gallus domesticus): prevalence, clinical disease, diagnosis and public health significance. Zoonoses Public Health. 2010;57(1):60-73.

4. Kijlstra A, Jongert E. Control of the risk of human toxoplasmosis transmitted by meat. Int J Parasitol. 2008;38(12):1359-70.

5. Jafari R, Sadaghian M, Safari M. Seroprevalence of Toxoplasma gondii Infection and Related Risk Factors in Tabriz City, Iran, 2008. J Res Health Sci. 2012;12(2):119-21.

6. Lopez-Castillo CA, de-la-Torre A. [Definition of acquired toxoplasmosis infection: when is it congenital or acquired?]. Arch Soc Esp Oftalmol. 2011;86(7):224-5.

7. Montoya JG, Liesenfeld O. Toxoplasmosis. Lancet. 2004;363(9425):1965-76.

8. Fayer R, Dubey JP, Lindsay DS. Zoonotic protozoa: from land to sea. Trends Parasitol. 2004;20(11):531-6.

9. Assmar M, Amirkhani A, Piazak N, Hovanesian A, Kooloobandi A, Etessami R. [Toxoplasmosis in Iran. Results of a seroepidemiological study]. Bull Soc Pathol Exot. 1997;90(1):19-21.

10. Barbosa IR, de Carvalho Xavier Holanda CM, de Andrade-Neto VF. Toxoplasmosis screening and risk factors amongst pregnant females in Natal, northeastern Brazil. Trans R Soc Trop Med Hyg. 2009;103(4):377-82.

11. Sambrook J, Russell DW. Molecular cloning: a laboratory manual. 3rd edCold Spring Harbor, New York: Cold Spring Harbor Laboratory Press; 2001.

12. Hashemi-Fesharki R. Seroprevalence of Toxoplasma gondii in cattle, sheep and goats in Iran. Vet Parasitol. 1996;61(1-2):1-3.

13. Dubey JP. Persistence of encysted Toxoplasma gondii in caprine livers and public health significance of toxoplasmosis in goats. $J$ Am Vet Med Assoc. 1980;177(12):1203-7.

14. Bekele T, Kasali OB. Toxoplasmosis in sheep, goats and cattle in central Ethiopia. Vet Res Commun. 1989;13(5):371-5.

15. Pita Gondim LF, Barbosa HV, Jr, Ribeiro Filho CH, Saeki H. Serological survey of antibodies to Toxoplasma gondii in goats, sheep, cattle and water buffaloes in Bahia State, Brazil. Vet Parasitol. 1999;82(4):273-6.

16. Sharma S, Sandhu KS, Bal MS, Kumar H, Verma S, Dubey JP. Serological survey of antibodies to Toxoplasma gondii in sheep, cattle, and buffaloes in Punjab, India.J Parasitol. 2008;94(5):1174-5.

17. Schoonman LB, Wilsmore T, Swai ES. Sero-epidemiological investigation of bovine toxoplasmosis in traditional and smallholder cattle production systems of Tanga Region, Tanzania. Trop Anim Health Prod. 2010;42(4):579-87.

18. Panadero R, Painceira A, Lopez C, Vazquez L, Paz A, Diaz P, et al Seroprevalence of Toxoplasma gondii and Neospora caninum in wild and domestic ruminants sharing pastures in Galicia (Northwest Spain). Res Vet Sci. 2010;88(1):111-5.

19. Berger-Schoch AE, Herrmann DC, Schares G, Muller N, Bernet D, Gottstein B, et al. Prevalence and genotypes of Toxoplasma gondii in feline faeces (oocysts) and meat from sheep, cattle and pigs in Switzerland. Vet Parasitol. 2011;177(3-4):290-7.

20. Chikweto A, Kumthekar S, Tiwari K, Nyack B, Deokar MS, Stratton G, et al. Seroprevalence of Toxoplasma gondii in pigs, sheep, goats, and cattle from Grenada and Carriacou, West Indies. J Parasitol. 2011;97(5):950-1.
21. Costa DG, Marvulo MF, Silva JS, Santana SC, Magalhaes FJ, Filho $\mathrm{CD}$, et al. Seroprevalence of Toxoplasma gondii in domestic and wild animals from the Fernando de Noronha, Brazil. JParasitol. 2012;98(3):679-80.

22. Lopes AP, Dubey JP, Neto F, Rodrigues A, Martins T, Rodrigues M, et al. Seroprevalence of Toxoplasma gondii infection in cattle, sheep, goats and pigs from the North of Portugal for human consumption. Vet Parasitol. 2013;193(1-3):266-9.

23. Dubey JP. A review of toxoplasmosis in cattle. Vet Parasitol. 1986;22(3-4):177-202.

24. Buffolano W, Gilbert RE, Holland FJ, Fratta D, Palumbo F, Ades AE. Risk factors for recent toxoplasma infection in pregnant women in Naples. Epidemiol Infect.1996;116(3):347-51.

25. Dubey JP, Towle A. Toxoplasmosis in Sheep: A Review and Annotated Bibliography:: The Commonwealth Institute of Parasitology; 1986.

26. Kozojed V, Blazek K, Amin A. Incidence of toxoplasmosis in domestic animals in Afghanistan. Folia Parasitol (Praha). 1976;23(3):273-5.

27. Hoghooghi-Rad N, Afraa M. Prevalence of toxoplasmosis in humans and domestic animals in Ahwaz, capital of Khoozestan Province, south-west Iran.J Trop Med Hyg. 1993;96(3):163-8.

28. Garcia-Bocanegra I, Cabezon O, Hernandez E, Martinez-Cruz MS Martinez-Moreno A, Martinez-Moreno J. Toxoplasma gondii in ruminant species (cattle, sheep, and goats) from southern Spain JParasitol. 2013;99(3):438-40.

29. Dubey JP, Thulliez P. Persistence of tissue cysts in edible tissues of cattle fed Toxoplasma gondii oocysts. Am JVet Res.1993;54(2):270-3.

30. Dubey JP, Beattie C. P. . Toxoplasmosis of Animals and Man.Boca Raton, FL: CRC Press; 1988.

31. Dubey JP, Adams DS. Prevalence of Toxoplasma gondii antibodies in dairy goats from 1982 to 1984 . J Am Vet Med Assoc 1990;196(2):295-6.

32. Mainar RC, de la Cruz C, Asensio A, Dominguez L, Vazquez-Boland JA. Prevalence of agglutinating antibodies to Toxoplasma gondii in small ruminants of the Madrid region, Spain, and identification of factors influencing seropositivity by multivariate analysis. Vet Res Commun. 1996;20(2):153-9.

33. Jolley WR, McAllister MM, McGuire AM, Wills RA. Repetitive abortion in Neospora-infected ewes. Vet Parasitol.1999;82(3):251-7.

34. Sharif M, Gholami S, Ziaei H, Daryani A, Laktarashi B, Ziapour SP, et al. Seroprevalence of Toxoplasma gondii in cattle, sheep and goats slaughtered for food in Mazandaran province, Iran, during 2005. Vet J. 2007;174(2):422-4.

35. Ragozo AM, Yai RL, Oliveira LN, Dias RA, Dubey JP, Gennari SM Seroprevalence and isolation of Toxoplasma gondii from sheep from Sao Paulo state, Brazil. J Parasitol. 2008;94(6):1259-63.

36. Hutchinson JP, Wear AR, Lambton SL, Smith RP, Pritchard GC. Survey to determine the seroprevalence of Toxoplasma gondii infection in British sheep flocks. Vet Rec. 2011;169(22):582.

37. Asgari Q, Sarnevesht J, Kalantari M, Sadat SJ, Motazedian $\mathrm{MH}$, Sarkari B. Molecular survey of Toxoplasma infection in sheep and goat from Fars province, Southern Iran. Trop Anim Health Prod. 2011;43(2):389-92.

38. Buxton D, Maley SW, Wright SE, Rodger S, Bartley P, Innes EA. Toxoplasma gondii and ovine toxoplasmosis: new aspects of an old story. Vet Parasitol. 2007;149(1-2):25-8.

39. Sadrebazzaz A, Haddadzadeh H, Shayan P. Seroprevalence of Neospora caninum and Toxoplasma gondii in camels (Camelus dromedarius) in Mashhad, Iran. Parasitol Res. 2006;98(6):600-1.

40. Hussein MF, Bakkar MN, Basmaeil SM, Gar el Nabi AR. Prevalence of toxoplasmosis in Saudi Arabian camels (Camelus dromedarius). Vet Parasitol. 1988;28(1-2):175-8.

41. Elamin EA, Elias S, Daugschies A, Rommel M. Prevalence of Toxoplasma gondii antibodies in pastoral camels (Camelus drom edarius) in the Butana plains, mid-Eastern Sudan. Vet Parasitol. 1992;43(3-4):171-5.

42. Hilali M, Romand S, Thulliez P, Kwok OC, Dubey JP. Prevalence of Neospora caninum and Toxoplasma gondii antibodies in sera from camels from Egypt. Vet Parasitol.1998;75(2-3):269-71.

43. Kamani J, Mani AU, Egwu GO. Seroprevalence of Toxoplasma gondii infection in domestic sheep and goats in Borno state, Nigeria. Trop Anim Health Prod. 2010;42(4):793-7. 
44. van der Puije WN, Bosompem KM, Canacoo EA, Wastling JM, Akanmori BD. The prevalence of anti-Toxoplasma gondii antibodies in Ghanaian sheep and goats. Acta Trop. 2000;76(1):21-6.

45. Ramzan M, Akhtar M, Muhammad F, Hussain I, HiszczynskaSawicka E, Haq AU, et al. Seroprevalence of Toxoplasma gondii in sheep and goats in Rahim Yar Khan (Punjab), Pakistan. Trop Anim Health Prod. 2009;41(7):1225-9.

46. Lopes WD, Santos TR, da Silva Rdos S, Rossanese WM, de Souza FA, de Faria Rodrigues JD, et al. Seroprevalence of and risk factors for Toxoplasma gondii in sheep raised in the Jaboticabal microregion, Sao Paulo State, Brazil. Res Vet Sci. 2010;88(1):104-6.

47. Wang CR, Qiu JH, Gao JF, Liu LM, Wang C, Liu Q, et al. Seroprevalence of Toxoplasma gondii infection in sheep and goats in northeastern China. Small Ruminant Res. 2011;97(1):130-3.

48. Alexander J, Stimson WH. Sex hormones and the course of parasitic infection. Parasitol Today. 1988;4(7):189-93.

49. Kittas S, Kittas C, Paizi-Biza P, Henry L. A histological and immu- nohistochemical study of the changes induced in the brains of white mice by infection with Toxoplasma gondii. Br J Exp Pathol.1984;65(1):67-74.

50. Skjerve E, Waldeland H, Nesbakken T, Kapperud G. Risk factors for the presence of antibodies to Toxoplasma gondii in Norwegian slaughter lambs. Prev Vet Med.1998;35(3):219-27.

51. Halos L, Thebault A, Aubert D, Thomas M, Perret C, Geers R, et al. An innovative survey underlining the significant level of contamination by Toxoplasma gondii of ovine meat consumed in France. Int J Parasitol. 2010;40(2):193-200.

52. Jokelainen P, Nareaho A, Knaapi S, Oksanen A, Rikula U, Sukura A. Toxoplasma gondii in wild cervids and sheep in Finland: northsouth gradient in seroprevalence. Vet Parasitol. 2010;171(3-4):331-6.

53. Schares G, Barwald A, Staubach C, Ziller M, Kloss D, Wurm R, et al. Regional distribution of bovine Neospora caninum infection in the German state of Rhineland-Palatinate modelled by Logistic regression. Int J Parasitol. 2003;33(14):1631-40. 